\title{
MANAGERIAL IMPLICATIONS OF THE RELATIONSHIP BETWEEN CUSTOMER CARE AND PURCHASE INTENTION IN ONLINE SHOPPING
}

Adnan Veysel ERTEMEL ${ }^{1}$

Mustafa Emre CIVELEK ${ }^{2}$
Received (Submission Date): 01/02/2019

Accepted (Acception Date): 02/03/2019

Published Date (Yayın Tarihi): 25/03/2019

\section{ABSTRACT}

This paper studies customer care as an important factor that affects the performance of B2C e-commerce websites. A survey was conducted to 464 Turkish B2C website customers. Analysis method of this study is partial least square structural equation modeling (PLS-SEM). Specifically, customer care in B2C e-commerce web sites is found to have direct effect on perceived value and indirect effect on purchase intention via perceived value and brand loyalty. Besides relationship between customer care and purchase intention was found as insignificant. The most important contribution of this research is the unveiling of the indirect relationship between customer care and purchase intention. This study also offers some important manageral suggestions for $B 2 C$ web sites.

Keywords: Online Shopping, Customer Care, Perceived Value, Brand Loyalty, Purchase Intention

JEL Codes: M10, M31

\section{ÇEVRIMIÇİ ALIŞVERIŞTE MÜSSTERI HİZMETLERININ SATINALMA NIYYTİ ÜZERINNDEKİ ETKISINININ YÖNETIMSEL ÇIKARIMLARI}

\section{$\ddot{O Z E T}$}

Bu makale, müststeri hizmetlerini B2C e-ticaret web sitelerinde performansin etkileyen önemli bir etken olarak incelemektedir. Çalışmada 464 Türk B2C web sitesi müşterisine anket yapllmıştır. Bu çalışmada kusmi en kü̧̈ük kareler yapısal eşitlik modellemesi (PLS-SEM) yöntemi kullanılmıştır. Özellikle, B2C e-ticaret web sitelerinde müşteri hizmetlerinin algllanan değeri doğrudan etkilediği ve algılanan değer ve marka sadakati üzerinden satın alma niyetini dolayl olarak etkilediği bulunmuştur. Ancak, müşteri hizmetleri ile satın alma niyeti arasında anlaml bir ilişki bulunmamıı̧str. Bu araştırmanın en önemli katkısl, müşteri hizmetleri ile satın alma niyeti arasindaki dolayli iliş̧kiyi ortaya koymasıdır. Bu çalışma aynı zamanda B2C web siteleri için yönetimsel bazı önemli öneriler getirmektedir.

Keywords: Çevrimiçi Allşveriş, Müşteri Hizmetleri, Algılanan Değer, Marka Bağlllı̆̆l, Satınalma Niyeti

${ }^{1}$ Dr. Öğr. Üyesi, İstanbul Ticaret Üniversitesi, avertemel@ticaret.edu.tr

${ }^{2}$ Dr. Öğr. Üyesi, İstanbul Ticaret Üniversitesi, ecivelek@ticaret.edu.tr http://orcid.org/0000-0002-5028-1096 http://orcid.org/0000-0002-2847-5126 


\section{INTRODUCTION}

For the past two decades, e-commerce has been transforming the global business environment in both $\mathrm{B} 2 \mathrm{~B}$ and $\mathrm{B} 2 \mathrm{C}$ context. This transformation has been more radical as the enabling technologies advance and consumers' rate of adoption increases. With its peculiar advantages like global reach, convenience, access to broad range of products and personalized service delivery, e-commerce medium is especially an attractive alternative in B2C ecommerce environment. Internet has radically altered the way of conducting business. It combines millions of businesses with potential customers worldwide. It has brought about new ways of interacting with the customers in a rich manner. Internet removes time, space and distance barriers by allowing the consumers to do business globally on a 7/24 basis (Diacon et al., 2011). As opposed to having one-way communication using traditional means, Internet enables two-way interaction which results in acquiring new insights about consumers. Additionally, Internet enables businesses to achieve cost savings and efficiency through ecommerce (Qin, 2010).

On the seller side of the phenomenon, conducting business via the Internet has the unique advantage of doing business for all kinds of suppliers across the globe. Looking from the buyer side, the Internet enables ease of price comparison and the ability to find long tail (niche) products for the customers. After all, convenience of shopping is the most crucial benefit which is provided by the Internet.

Electronic commerce can simply be described as purchasing and selling goods and services in online environment. E-commerce rate as a percentage in the whole commerce is steadily increasing worldwide. Global e-commerce volume has reached 2.8 trillion dollars as of 2018, with 12 percentage in yearly growth rate, which accounts for one tenth of all retail commerce (eMarketer, 2018). In parallel to the global trend, in United States, retail ecommerce volume has reached 560 billion dollars which account for 9.8 percent of all sales (Statista, 2019). Globally conducted retail e-commerce volume is expected to reach 4.8 trillion dollars in 2021 which will account for 18 percent of all commerce (Statista, 2019). Hence, it can be concluded that looking from both business and consumer perspectives, ecommerce is fastly becoming a part of our daily lives. As the Internet and Smartphone penetration rates increase and the related enabler technologies advance, conducting ecommerce has been more and more viable worldwide. 
Online shopping is a narrow scoped concept under e-Commerce which is covering activities of buying goods or services over the Internet. This phenomenon is buying side of B2C (business-to-consumers) e-commerce that specifically deserves attention for studying. Online shopping has become an integral part of consumers' daily consumption habits. Using B2C e-commerce web sites, consumers can find a more convenient shopping experience and have access to a broad range of products at their fingerprints. B2C e-commerce web site usage adoption rates increase as tech-savvy newer generations are now able shop online (Çemberci, Sudak, Aşçı, Öz, \& Civelek, 2014). Additionally, consumers find it easier to shop online due to ever simplified user experience provided in online environment.

An excess of literature has studied e-commerce from various viewpoints. However, as for literature that studies e-commerce brands in general and the key dimensions that contribute to brands' performance particularly in B2C context is rather limited. According to Keller (2003), brand performance is a prerequisite for brand loyalty (Woodside, Megehee , \& Ogle , 2009). In online environment e-brand loyalty is equivalent of brand loyalty. Therefore, e-commerce brand performance is related to e-brand loyalty (Gommans, Krishnan, \& Scheffold, 2001). Specifically, this paper regards customer care as an important dimension that affects brand performance. To demystify the mechanism behind this relationship, an analysis was conducted on the effect of customer care on purchase intention via perceived value and loyalty. In conceptual background, constructs of the research model which are customer care, perceived value, brand loyalty and purchase intention are introduced. Afterwards, methodology used in this study are explained. Consequently, research findings and their implications are discussed.

\section{CONCEPTUAL BACKGROUND}

\subsection{Customer Care}

Customer care can be described as the degree to which e-commerce web site customers are informed about the availability of products and product order status (Srivinisan, 2002). In B2C e-Commerce customer interactions do not take place face to face. On the contrary, in online medium, this relation turns into screen to face mode (Joseph, 2015). Customer care is also inclusive of the level of efforts the brand undertake to mitigate the risk of service failure or breakdown (Srivinisan, 2002). 


\subsection{Perceived Value}

Perceived value is a widely acknolowdged and used term to assess brands' perception. It is based on equity theory (Oliver et al., 1988). It is stated that when consumers consider whether they were treated equitably, they have a perception regarding the benefit they got. This is based on the ratio of costs and sacrifices versus what is got (Bolton et al., 1992). These costs and sacrifices might be monetary,waste of time and so on.

In e-commerce environment, this phenomenon is particularly related to maintaining long term relationship with the customers. Online customers expect to be equitably treated. Moreover, bacause of the fierce competition in e-commerce domain, in order to acquire customer loyalty it is necessary to increase perceived value (Yang et al., 2004).

\subsection{Brand Loyalty}

Oliver (1998) defines brand loyalty as a deeply held commitment to rebuy from a brand irrespective of situational factors. Boulding et al (1993), on the other hand, defines brand loyalty as customers' inclination to continue to do business with a brand and recommend it to others. Brand loyalty is critical in brand performance in that it takes a far less time, effort and money to keep loyal customers as opposed to nonloyal customers. In ecommerce environment, this becomes especially important as businesses compete to cut their marketing costs.

\subsection{Purchase Intention}

The theory of planned behavior asserted that behavioral intention is the main predictor of purchase behavior (Ajzen, 1991). E-commerce web sites should somehow link their activities to business performance. Business performance of e-Commerce web sites are related to actual buying behavior of the customers. In this sense, previous literature uses purchase intention to imply actual behavior (Lin, 2006). Therefore, in this study, purchase intention was used to predict actual behavior.

\section{RESEARCH MODEL AND HYPOTHESES DEVELOPMENT}

In Figure 1, constructs and hypotheses in the research model are shown. In the conceptual model of the research there are four hypotheses. These hypotheses were developed to understand the impact of customer care on the purchase intention through perceived value and brand loyalty. 


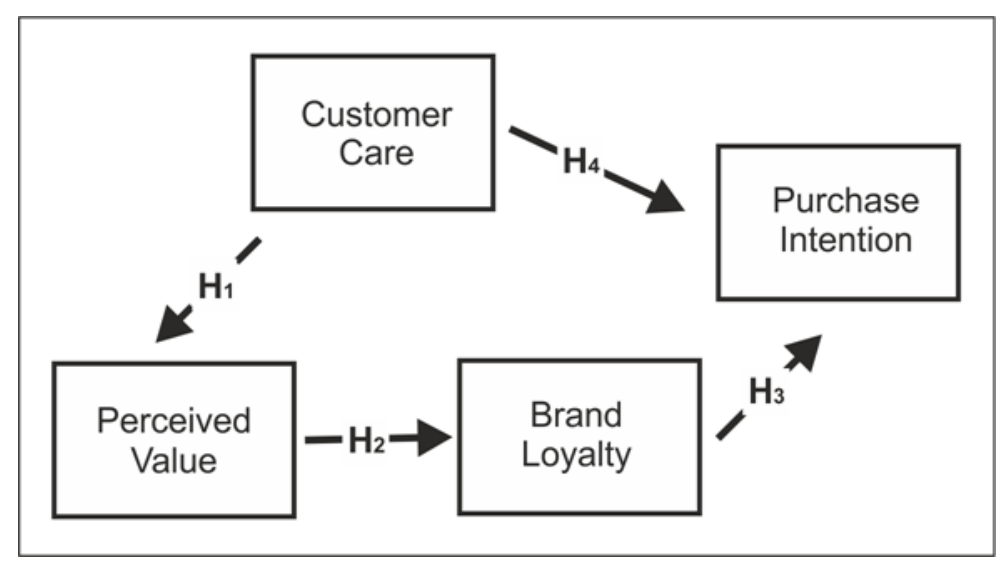

Figure 1. Initial Research Model

\subsection{The Relationship between Customer Care and Perceived Value}

Jiang et al. (2016) defines customer care, in e-commerce context, as the level on which an e-business tailors its services to meet individualized needs of its customers. The internet medium, by nature, allows the brands to attract and keep customers via personalized services. Srivinisan (2002) has shown that customer care is one of the key drivers of perceived value and recommended the brands to build and sustain long-term relationship with the customers. Extant literature has also demonstrated the negative effect of service failues on customer perceived value (Bolton et al., 1992).

Thus, in the light of the above metioned studies, following hypothesis is developed:

$\mathrm{H}_{1}$ : Customer Care has a positive effect on Perceived Value.

\subsection{The Relationship between Perceived Value and Brand Loyalty}

Chen et al. (2013) and Zeng et al. (2009) have identified that perceived value, in ecommerce, is the foremost motivation for customer loyalty. Likewise, Yang et al. (2004) have suggested positive effect of customer perceived value on brand loyalty in online medium. Furthermore, Oliver et al. (1988) and Civelek and Ertemel (2018) mention that raised perceived value may significantly exert positive influence on brand loyalty.

Thus, in the light of the above metioned studies, following hypothesis is developed:

$\boldsymbol{H}_{2}$ : Perceived Value has a positive effect on Brand Loyalty. 


\subsection{The Relationship between Brand Loyalty and Purchase Intention}

Different studies in previous literature on e-commerce have demonstrated that brand loyalty is a predictor of purchase intention (Wang et al., 2006; Kamariah et al., 2005). Therefore, higher level of brand loyalty in e-Commerce web sites leads to a stronger likelihood of purchase intention. Schultz (2000) mentioned that loyalty to the brand in online shopping is especially important due to the highly competitive nature of online medium. Consequently, it can be said that loyal customers of an e-commerce web site have more purchase intention than others.

Thus, in the light of the above metioned studies, following hypothesis is developed:

H3: Brand Loyalty has a positive effect on Purchase Intention.

\subsection{The Relationship between Customer Care and Purchase Intention}

Bitner et al. (1990) have shown that service unavailability or breakdown negatively effects purchase intention. Similarly, Boulding et al. (1993) and Kelley et al. (1993) concluded that the level of customer care is an antecedent of purchase intention.

Thus, in the light of the above metioned studies, following hypothesis is developed:

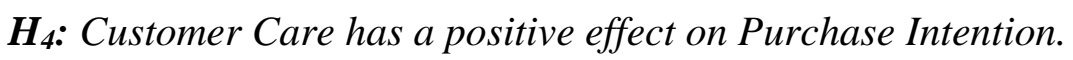

\section{RESEARCH METHODOLOGY}

Partial least square structural equation modeling (PLS-SEM) was used as analysis method in this study. Quantative data were gathered by means of a questionnaire containing statements ordinal Likert scale in five-point. This scale is varying from strongly disagree to strongly agree. Initially, the validity and reliability of the scales were tested. Afterwards, in order to test the hypotheses which are bring forward in the conceptual research model, partial least square structural equation modeling method was used. PLS-SEM analysis method is variance-based multivariate analysis. It is a second generation method. In this method, structural and measurement models can be analyzed jointly (Civelek, 2018). SmartPLS statistics program was utilized for analyses.

\subsection{Measures and Sampling}

For measuring customer care construct, the scale adopted from Jiang et al. was used. Same scale was used to measure brand loyalty and perceived value (Jiang, Jun, Yang, 2016). For measuring purchase intention, the scale taken from Chen et al. was adopted (Chen, Teng, 
2013). 464 of the distributed questionnaires were valid. The survey was performed in the prominent cities throughout Turkey according to probability sampling. Data collected in the first quarter of 2018. Face to face method was used. In the sample, 240 persons are male and 224 persons are female.

\subsection{Validity and Reliability of Constructs}

For purification of data, firstly, the exploratory factor analysis was performed. 20 items remained after purification process. Subsequently, the confirmatory factor analysis was conducted for remaining items to demonstrate the constructs with convergent validity (Anderson \& Gerbing, 1988). In Table 1, the findings of the confirmatory factor analysis and outher loadings (loads of reflective incidators) are shown. Each item is close to 0.7 and significant. These results confirm that the scales have convergent validity.

Table 1. Factor Loads

\begin{tabular}{ccc}
\hline Variables & Items & Factor Loads \\
\hline & Cca0111 & 0.788 \\
Customer Care & Cca0212 & 0.862 \\
& Cca0313 & 0.729 \\
& Cca0414 & 0.753 \\
& Cca0515 & 0.764 \\
Perceived Value & Cca0616 & 0.823 \\
\hline & Pva0434 & 0.777 \\
& Pva0535 & 0.782 \\
p $<0.05$ for all items & Pva0333 & 0.620 \\
& Pva0131 & 0.672 \\
& Pva0232 & 0.790 \\
\hline & Bly0641 & 0.683 \\
& Bly0136 & 0.848 \\
& Bly0439 & 0.698 \\
& Bly0237 & 0.828 \\
& Bly0338 & 0.806 \\
& Bly0540 & 0.764 \\
\hline & Pin0142 & 0.840 \\
& Pin0344 & 0.891 \\
& Pin0243 & 0.889 \\
\hline & & \\
& &
\end{tabular}

The square roots of average variance extracted values were calculated for each construct. In order to determine discriminant validity, these values were compared with correlation values among the constructs in the corresponding column according to fornelllarcker criterion (Hair, Hult, Ringle, \& Sarstedt, 2017). In Table 2, the values in brakets 
designate the square root of AVE value of each construct. As indicated in Table 2, the square roots of average variance extracted values are bigger than the correlation coefficients in corresponding column (Byrne, 2010). Reliability of the scales was also determined. Cronbach $\alpha$ and Composite reliability values are bigger than the threshold value (i.e. 0.7) (Fornell \& Larcker, 1981). In Table 2, Cronbach $\alpha$ values, means and standard deviations, Pearson correlation coefficients, composite reliabilities, AVE values of the constructs are indicated.

Table 2. Descriptive Statistics and Reliability

\begin{tabular}{lcccc}
\hline Variables & 1 & 2 & 3 & 4 \\
\hline 1.Customer Care & $(0.788)$ & & & \\
2.Perceived Value & $0.383^{*}$ & $(0.731)$ & & \\
3.Brand Loyalty & $0.425^{*}$ & $0.558^{*}$ & $(0.773)$ & \\
4.Purchase Intention & $0.287^{*}$ & $0.420^{*}$ & $0.630^{*}$ & $(0.873)$ \\
\hline Composite reliability & 0.907 & 0.851 & 0.899 & 0.906 \\
\hline Average variance ext. & 0.621 & 0.535 & 0.599 & 0.763 \\
\hline Cronbach $\alpha$ & 0.877 & 0.787 & 0.865 & 0.845 \\
\hline Mean & 3.60 & 3.74 & 3.85 & 3.98 \\
\hline Standard Deviation & 0.74 & 0.65 & 0.71 & 0.75 \\
\hline Note: Diagonals in brackets indicate the square root of AVEs. & &
\end{tabular}

\section{TEST OF HYPOTHESES}

For performing tests of hypotheses suggested in the conceptual model, PLS-SEM method was used. This method is a nonparametric statistical method. Therefore, for testing the significance of the estimates, this method uses bootstrap procedure. $\mathrm{P}$ values smaller than 0.05 are significant according to this procedure (Civelek, 2018). In Table 3, test results of the hypotheses are shown.

Table 3. Hypotheses Test Results

\begin{tabular}{lc}
\hline Relationships & $\begin{array}{c}\text { Standardized } \\
\text { Coefficients }\end{array}$ \\
\hline Customer Care $\rightarrow$ Perceived Value & $0.383^{*}$ \\
Perceived Value $\rightarrow$ Brand Loyalty & $0.558^{*}$ \\
Brand Loyalty $\rightarrow$ Purchase Intention & $0.620^{*}$ \\
Customer Care $\rightarrow$ Purchase Intention & 0.023 \\
\hline $\mathrm{p}<0.05$ &
\end{tabular}

In Figure 2, structural model and PLS-SEM analysis result are shown. As shown in Table 3, $\mathrm{H}_{1}, \mathrm{H}_{2}$ and $\mathrm{H}_{3}$ are supported and $\mathrm{H}_{4}$ is not supported. According to the analysis 
results, there is a significant positive relationship between customer care and perceived value. There are significant positive relationships between perceived value and brand loyalty and between brand loyalty and purchase intention. But direct relationship among customer care and purchase intention was not found statistically significant.

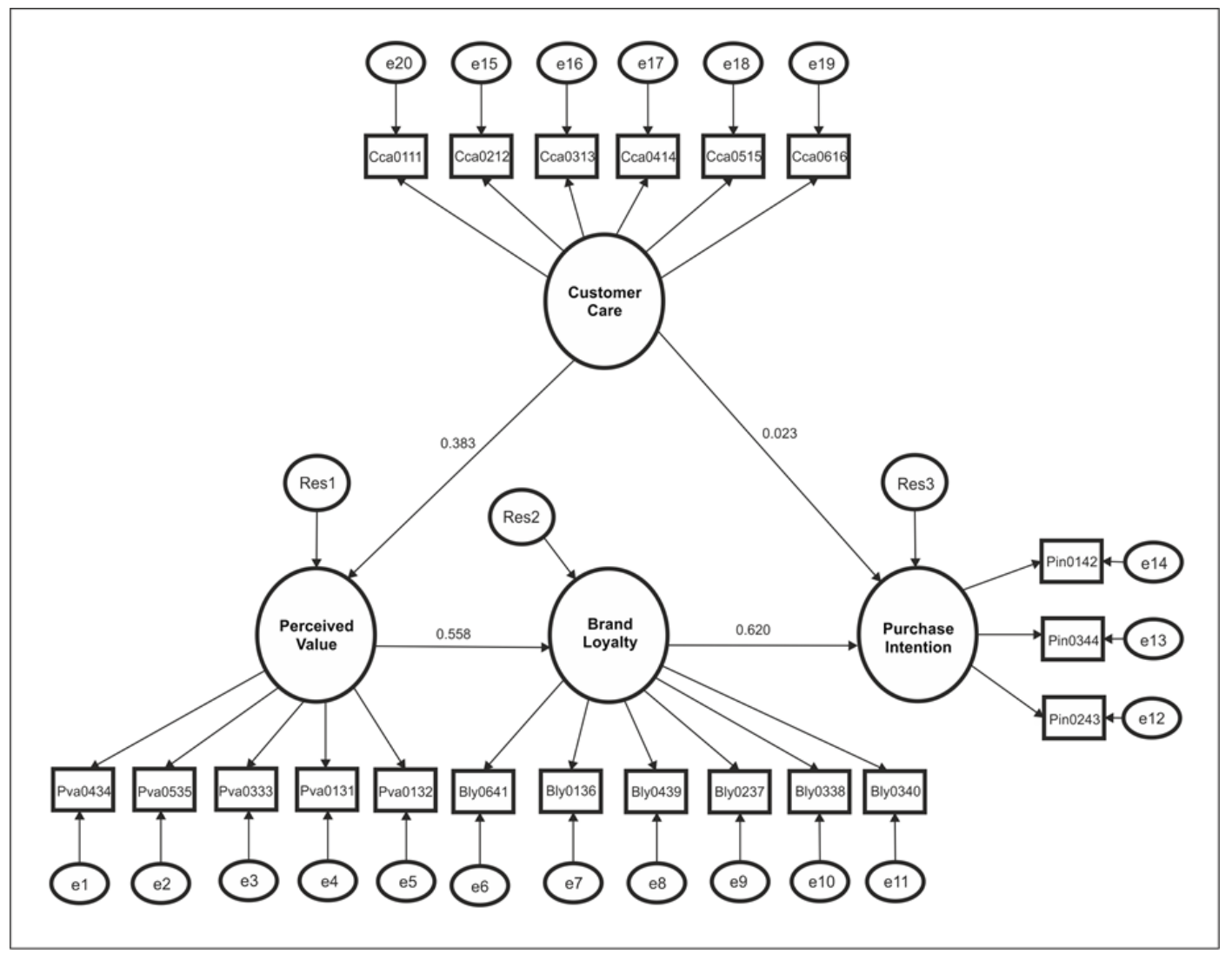

Figure 2. Structural Model Analysis

In PLS-SEM, the coefficient determination $\left(\mathrm{R}^{2}\right)$ is the most prefered measure. It is used to assess the path models. $\mathrm{R}^{2}$ value indicates the predictive power of the model. This value represents the extent of variance explained and means combined effects of independent latent variables on an endogenous latent construct. A rule of thumb is used to determine the satisfactory level of $\mathrm{R}^{2}$. Values above 0 are acceptable and above 0.20 can be regarded as high (Hair, Hult, Ringle, \& Sarstedt, 2017). The values found as a result of the analysis are acceptable as seen in Table 4.

Table 4. $\mathrm{R}^{2}$ Values of the Dependent Variables

\begin{tabular}{|c|c|}
\hline Variables & $\mathrm{R}^{2}$ \\
\hline Perceived Value & 0.147 \\
\hline Brand Loyalty & 0.311 \\
\hline Purchase Intention & 0.397 \\
\hline
\end{tabular}


Effect size $\mathrm{f}^{2}$ is another measure and represents the effect of a construct on another construct. It is found by neglecting the construct from the model. $\mathrm{f}^{2}$ refers to the change in $\mathrm{R}^{2}$ when a construct neglected in the model. To evaluate $\mathrm{f}^{2}$, following figures of $0.02,0.15$ and 0.35 are used. These figures mean small, medium and strong effects respectively (Cohen, 1988). According to the results $\mathrm{f}^{2}$ value of customer care-perceived value indicate medium effect as shown in Table 5.

Table 5. Effect Size $\left(\mathrm{f}^{2}\right)$ Values

\begin{tabular}{l|l}
\multicolumn{1}{c}{ Relations } & $\mathrm{f}^{2}$ \\
\hline Customer Care $\rightarrow$ Perceived Value & 0.172 \\
Perceived Value $\rightarrow$ Brand Loyalty & 0.452 \\
Brand Loyalty $\rightarrow$ Purchase Intention & 0.522 \\
Customer Care $\rightarrow$ Purchase Intention & 0.001 \\
\hline
\end{tabular}

Another measure is Stone-Geisser's $Q^{2}$ value (Geisser, 1974). For each dependent variable, $\mathrm{Q}^{2}$ value specifically indicates predictive relevance of path model. It is only calculated for dependent variables in the model. To calculate $\mathrm{Q}^{2}$ values, blindfolding procedure is used. $\mathrm{Q}^{2}$ values larger than zero indicate predictive relevance for a certain dependent variable in the model. But, values of zero or below designate lack of predictive relevance. Table 6 indicates $\mathrm{Q}^{2}$ values of each dimension. As seen in the Table 6, all the dependent variables have predictive relevance.

Table 6. Dependent Variable $Q^{2}$ Values

\begin{tabular}{l|c}
\multicolumn{1}{c}{ Variables } & $\mathrm{Q}^{2}$ \\
\hline Perceived Value & 0.065 \\
\hline Brand Loyalty & 0.172 \\
\hline Purchase Intention & 0.281
\end{tabular}

\section{CONCLUSION}

In the light of research findings, it can be concluded that customer care does not have a direct effect on purchase intention in online shopping. The research results do, however, indicate that customer care effects purchase intention via perceived value and brand loyalty indirectly. The results of this research have some significant managerial implications for the practitioners working in $\mathrm{B} 2 \mathrm{C}$ area. Firstly, we can conclude that improving customer care activities such as timely delivery, prompt reply to inquiries etc. do not exert positive influence on purchase intention immediately. On the other hand, strictly engaging in such activities is expected to increase brand perceived value in the long run. Naturally, this process takes time. Consequatively, increased perceived value positively effects brand loyalty over time. In sum, 
for B2C e-commerce web sites, improvements in customer care activities can only be performed through brand perveived value and brand loyalty over the long run.

Looking from managerial perspective, success of B2C businesses is strictly related to quality of the web site. Information quality, system quality and service quality are basic characteristics of B2C web sites. Improving web site system is one of the important aspects of the customer care activities. Additionaly, improving logistics processes is another aspect of success. Logistics activities indirectly affect customer satisfaction in B2C web sites (Civelek, 2018). This research also makes an important contribution to the current e-commerce literature by explaining the relationship among customer care, perceived value, brand loyalty and purchase intention. Extant literature posited that customer care has a positive effect on purchase intention. However, conversely, this research unveils the indirect relationship via perceived value and brand loyalty because hypothesis which put forward direct relation was rejected. Consequently, progressive relationships among customer care, perceived value, brand loyalty and purchase intention have been proved. The most important limitation of this study is the small sample size. In the future, this study can be repeated with larger samples.

Contrary to the findings of Bitner et al. (1990), Boulding et al. (1993) and Kelley et al. (1993), this study found out that customer care does not exert positive effect on purchase intention in $\mathrm{B} 2 \mathrm{C}$ e-commerce web sites. Other relationships in the research model were founded as congruent with extant literature. 


\section{REFERENCES}

Ajzen, I. (1991). The theory of planned behavior. Organizational behavior and human decision processes, 50(2), $179-211$.

Anderson, J. \& Gerbing, D. (1988). Structural Equation Modelling in Practice: A Review and Recommended Two-Step Approach. Psychological Bulletin.

Bitner, Mary Jo, Bernard H. Booms, and Mary S. Tetreault (1990). The service encounter: diagnosing favorable and unfavorable incidents, Journal of Marketing, 54 (January), 71-84

Bolton, Ruth N. and James H. Drew (1992). Mitigating the effect of service encounters, Marketing Letters, 3 (January), 57-70

Boulding, W., Kalra, A., Staelin, R., \& Zeithaml, V. A. (1993). A dynamic process model of service quality: from expectations to behavioral intentions. Journal of marketing research, 30(1), 7.

Byrne, B. M. (2010). Structural Equation Modeling with AMOS. New York: Routledge Taylor \& Francis Group. Chen, M. Y., \& Teng, C. I. (2013). A comprehensive model of the effects of online store image on purchase intention in an e-commerce environment. Electronic Commerce Research, 13(1), 1-23.

Cohen, J. (1988). Statistical Power Analysis for the Behavioral Sciences. Mahwah: Lawrence Erlbaum.

Civelek, M. (2018). Comparison of Covariance-Based and Partial Least Square Structural Equation Modeling Methods under Non-Normal Distribution and Small Sample Size Limitations. Eurasian Econometrics, Statistics \& Empirical Economics Journal, 10, 39-50.

Civelek, M. (2018). e-Ticaret Web Sitelerinde Müşteri Memnuniyeti. İstanbul: Beta.

Civelek, M. (2018). Essentials of Structural Equation Modeling. Lincoln: University of Nebraska Lincoln-Zea Books.

Civelek, M. E., \& Ertemel, A. V. (2018). The effect of product portfolio on purchase intention in e-commerce web sites.

Çemberci, M., Sudak, M., Aşçı, S., Öz, S., \& Civelek, M. (2014). Y Neslinin Örgüt Ortamındaki Davranış Farklılıklarının Analizi. Online Academic Journal of Information Technology, 5(15), 57-74.

Diacon, P. E., \& Donici, A. N. (2011). E-commerce across European Union. CES Working Papers, 3(3), 390397.

EMarketer (2016), Retail E-commerce Worldwide 2016-2021. https://www.emarketer.com/Chart/RetailEcommerce-Sales-Worldwide-2016-2021-trillions-change-of-total-retail-sales/215138, Access date, 26.01.2019

Fornell, C. \& Larcker, D. (1981). Evaluating Structural Equation Models with Unobservable Variables and Measurement Error. Journal of Marketing Research, 18(1), 39-50.

Geisser, S. (1974). A predictive approach to the random effects model. Biometrika, 61, 101-107.

Gommans, M., Krishnan, K., \& Scheffold, K. (2001). From brand loyalty to e-loyalty: a conceptual framework. Journal of Economic and Social Research, 3(1), 43-58. 
Hair, J., Hult, G., Ringle, C., \& Sarstedt, M. (2017). A primer on partial least squares structural equation modeling PLS-SEM. Los Angeles: SAGE.

Jiang, L., Jun, M., \& Yang, Z. (2016). Customer-perceived value and loyalty: how do key service quality dimensions matter in the context of B2C e-commerce?. Service Business, 10(2), 301-317.

Joseph, P. (2015). E-Commerce. Mumbai: Prentice Hall India Pvt., Limited.

Kamariah, N.., \& Salwani, S. (2005). Determinants of online shopping intention, 167-172

Kelley, Scott W., Douglas K. Hoffman, and Mark A. Davis (1993). A typology of retail failures and recoveries, Journal of Retailing, 69 (winter), 429-452

Lin, L. Y., \& Chen, C. S. (2006). The influence of the country-of-origin image, product knowledge and product involvement on consumer purchase decisions: an empirical study of insurance and catering services in Taiwan. Journal of consumer Marketing, 23(5), 248-265.

Oliver, R. L., \& DeSarbo, W. S. (1988). Response determinants in satisfaction judgments. Journal of consumer research, 14(4), 495-507.

Qin, Z. (Ed.). (2010). Introduction to E-commerce. Springer science \& business media.

Schultz, D. (2000) “Customer/Brand Loyalty in an Interactive Marketplace,” Journal of Advertising Research, 40 (3): 41-53.

Srinivasan, S. S., Anderson, R., \& Ponnavolu, K. (2002). Customer loyalty in e-commerce: an exploration of its antecedents and consequences. Journal of retailing, 78(1), 41-50.

Statista. (2019). Statista. Accessed: https://www.statista.com/statistics/272391/us-retail-e-commerce-salesforecast/

Turban, E., Outland, J., King, D., Lee, J. K., Liang, T. P., \& Turban, D. C. (2017). Electronic commerce 2018: a managerial and social networks perspective. Springer.

Wang, H. C., Pallister, J. G., \& Foxall, G. R. (2006). Innovativeness and involvement as determinants of website loyalty: II. Determinants of consumer loyalty in B2C e-commerce. Technovation, 26(12), 1366-1373.

Woodside, A., Megehee , C., \& Ogle , A. (2009). Perspectives on Cross-Cultural, Ethnographic, Brand Image Storrytelling, Unconscious Needs, and Hospitality Guest Research. Bingley: Emerald Group Publishing Limited.

Yang, Z., \& Peterson, R. T. (2004). Customer perceived value, satisfaction, and loyalty: The role of switching costs. Psychology \& Marketing, 21(10), 799-822.

Zeng, F., Hu, Z., Chen, R., \& Yang, Z. (2009). Determinants of online service satisfaction and their impacts on behavioural intentions. Total Quality Management, 20(9), 953-969. 